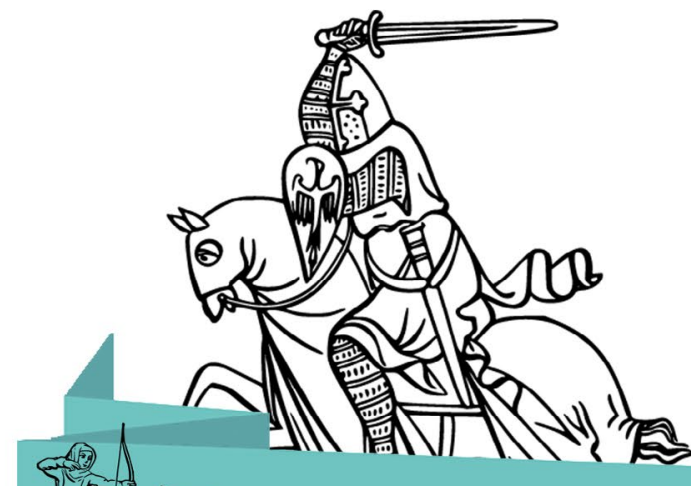

ISSN 2660-9169

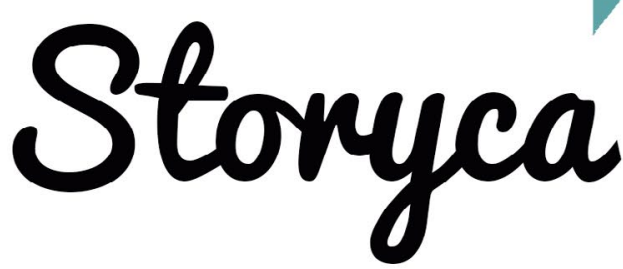

\title{
El caballero del pueblo, los trabajadores y los oprimidos: una lectura de Almer, cómic neomedieval argentino
}

\author{
Gabriela Cipponerl \\ JuAn MANuel LACALle \\ KAILA YANKELEVICH
}

Universidad de Buenos Aires

A Robin Wood, quien nos dejó el pasado 17 de octubre para colarse eterno entre estas y muchas otras líneas.

\section{Introducción}

La cercanía artística entre el arte secuencial ${ }^{1}$ y la Edad Media se plasma en una gran variedad de medios: desde miniaturas en manuscritos, como las del Jeu de Robin et Marion (Lacalle, 2012), hasta soportes textiles, como el tapiz de Bayeux (Gallo León y Játiva Miralles, 2017), que se encargan de contar un relato a través de imágenes. Las creaciones modernas del cómic que trabajan con el imaginario medieval han sido analizadas

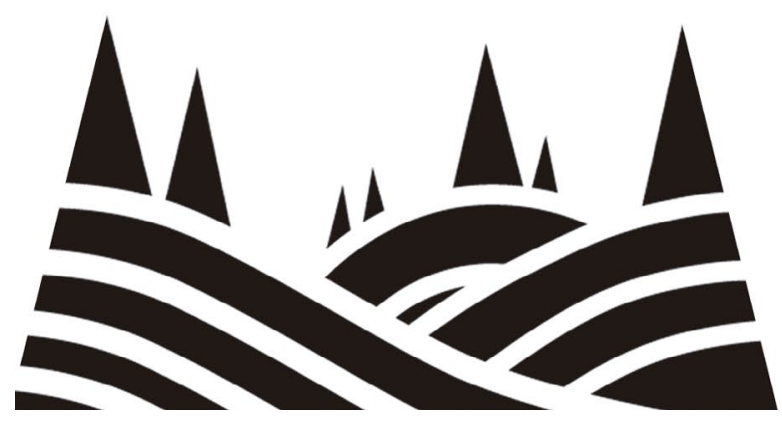

1. Este es el término que emplea Will Eisner (1985), uno de los primeros en examinar el género, y que consideramos más adecuado para referirnos a producciones históricas que combinan secuencias de imágenes y texto. 
de manera fructífera aunque todavía escasa. Baste aquí recomendar, para un panorama del ámbito hispánico, el artículo de Llosa Sanz (2019), y para la materia artúrica en general, en la que se enmarca la publicación que abordaremos, la lectura de Blanc (2016) y Torregrossa (2004).

Entre las distintas manifestaciones estéticas neomedievales que se dan en la Argentina, el ámbito de la historieta es uno de los menos estudiados. Si bien existen numerosos cómics de temática histórica, algunos realizados por autores de enorme influencia, ${ }^{2}$ pocos se centran en la Edad Media. No debemos soslayar, por otra parte, que una de las máximas producciones historietistísticas del país, El eternauta (1957-1959), de Héctor Germán Oesterheld y Francisco Solano López, pertenece al ámbito de la ciencia ficción y la aventura; espacios que no resultan ajenos a las ficciones neomedievales más emblemáticas, como la novela Un yanqui en la corte del rey Arturo (1889) de Mark Twain, o Camelot 3000 (1982-1984), de Mike W. Barr y Brian Bolland, ${ }^{3}$ por mencionar unos pocos ejemplos.

Muchos cómics argentinos de importancia bordean el período medieval sin adentrarse del todo en él, como sucede con aquellos que sitúan a sus personajes en la América de la Conquista. Tal es el caso de Alvar Mayor, que cuenta las aventuras del caballero andante homónimo en el Nuevo Mundo, guionado por Carlos Trillo y dibujado por Enrique Breccia, y aparecido por primera vez en el n. ${ }^{\circ} 36$ de la revista Skorpio en octubre de 1977. Otro ejemplo es la serie Ibáñez, del guionista paraguayo Robin Wood (de quien volveremos a hablar enseguida) y, una vez más, del dibujante argentino Enrique Breccia, cuyo primer ejemplar se publicó en enero de 1983 en el n. 13 de la revista D'artagnan. También en la época posterior a la Conquista española, pero contextualizado en Europa, se desarrolla Dago, creación de Robin Wood y Alberto Salinas publicada por la editorial Columba entre 1981 y 1996 (aunque actualmente sigue saliendo en Italia, producto de la tarea de Carlos Gómez y Joan Mundet). En otro orden, algunos episodios de la muy prolífica serie Gilgamesh, el inmortal, historieta gestada por el dibujante Lucho Olivera en 1969, están situados en la Edad Media y en la Modernidad temprana (véanse, sobre todo, los episodios 8,9 y 10 de la serie guionada por Wood); historieta gestada por el dibujante Lucho Olivera en 1969. Esta colección contó con guionistas diversos: Wood (quien reescribió desde 1980 la parte original, finalizada en 1975), Ricardo Ferrari y Alfredo Julio Grassi. Un poco posterior es la reelaboración de la historia del poderoso Merlín, realizada por el ya mencionado Wood y el dibujante Enrique "Quique» Alcatena en 1993, que consta de nueve números en blanco y negro. Una cuestión interesante aquí es la creación de dos mundos, el mágico y el humano, cuya coexistencia se ve imposibilitada debido a la bestialidad de los hombres. Es quizás por este motivo que el foco está puesto sobre la corrupción y la caída de los mundos

2. Se puede pensar en obras tan dispares y centradas en épocas tan distintas como la fructífera serie de Inodoro Pereyra, realizada por Roberto Fontanarrosa desde 1972, la adaptación de El matadero, de Esteban Echeverría, por Enrique Breccia (1984), o las más cercanas en el tiempo Fueye (2008), de Jorge González, y Dora (2009-), de Ignacio Minaverry.

3. Para un acercamiento a los cómics Camelot 3000 y Dracula vs King Arthur, en los que la leyenda artúrica aparece en relación con la ciencia ficción y la fantasía, véase Cipponeri y Yankelevich (2020). 
(un aspecto para el que la materia artúrica ha sido muy fructífera a lo largo de los años), la añoranza de un pasado mejor y la marcada prevalencia de un vocabulario que rodea el campo semántico de palabras como guerra, muerte, destrucción, desintegración, hambre, bestialidad. Sin duda, el Merlín, que también tiene presente el valor de la conciencia de clase, es una obra que amerita un tratamiento exclusivo y, por consiguiente, será objetivo de un análisis próximo.

En el presente latinoamericano se cuenta con una gran cantidad de flamantes publicaciones de cómic neomedieval - que exploran universos relacionados, muchas editadas en línea o por editoriales independientes. Un claro ejemplo es Ottar, de Esteban «Erre» Quinteros, disponible en la página de G-Cómics desde el año 2020, que desarrolla las aventuras de Ottar en un universo que recuerda a la mitología nórdica. En la misma editorial apareció recientemente El portador de la llama (2019), de Feli White, una historieta de aventuras en donde los personajes son animales antropomórficos. Del mismo autor son, además, los dos volúmenes de Thunder Breaker (Módena, 2018 y 2019), cuya protagonista debe recuperar un huevo de dragón robado. Igualmente ubicada en un universo fantasy, El clan de Daurdain, de la argentina Macarena García Cuerva y editada por In Bocca al Lupo, cuenta en la actualidad con tres volúmenes (2018, 2019 y 2021). Por último, podríamos incluir en este breve recorrido La épica aventura de Axe el Rudo (2018), del chileno Matías Haakon, editada por Brotherhood Comics.

Luego de este escueto panorama, que asumimos incompleto por el fin aquí perseguido, nos interesa detenernos en esta oportunidad en la serie Almer de Capitán Manu, pseudónimo de Manuel Loza, oriundo de Quilmes, Provincia de Buenos Aires. Con motivo del presente artículo para Storyca, nos pusimos en contacto con Manuel, quien con la mejor predisposición accedió a tener un intercambio por correo electrónico, donde pudimos consultarle por distintos aspectos que nos parecían especialmente relevantes para el caso (como, por ejemplo, las fuentes

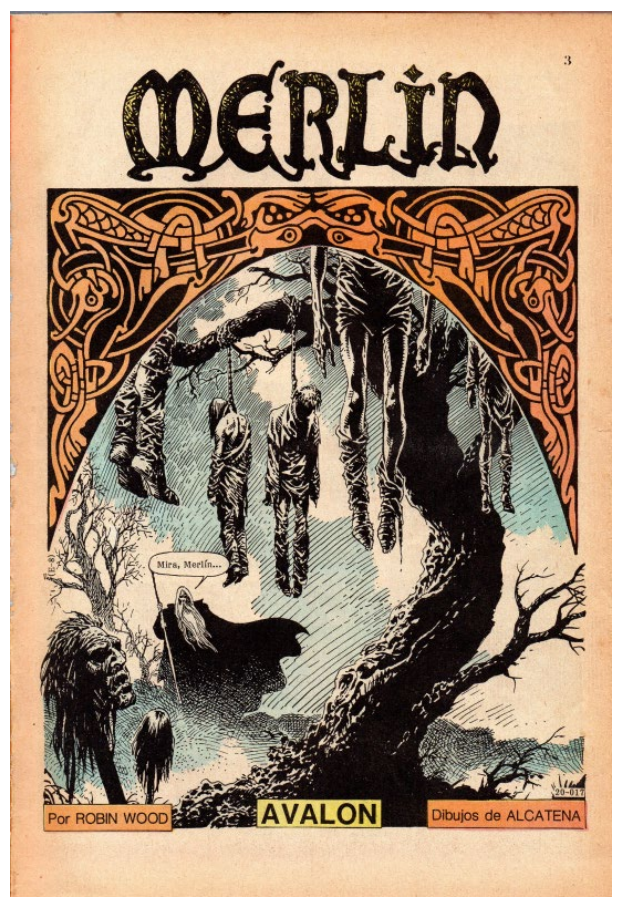

Merlín, Wood y Alcatena

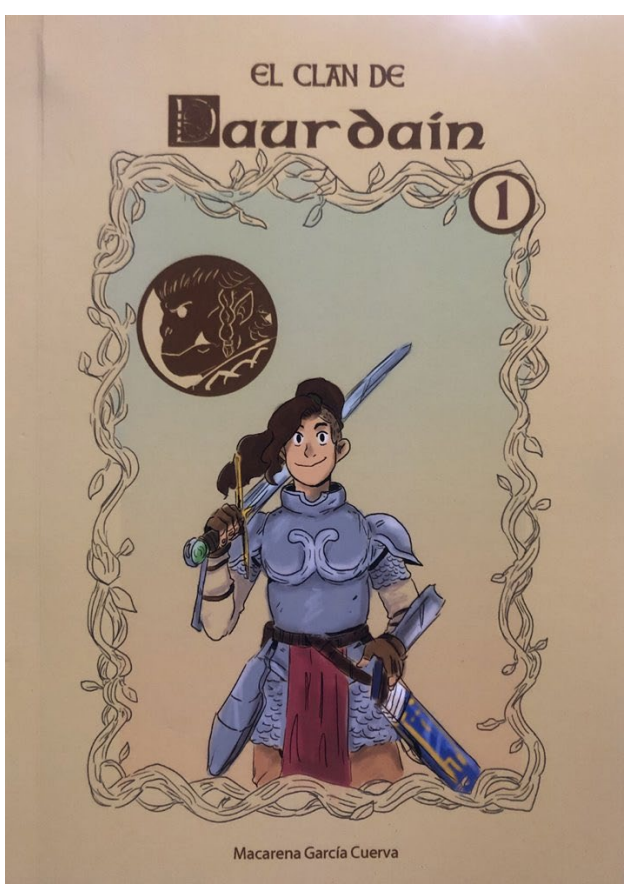

El clan de Daurdain, Macarena García Cuerva 
medievales y neomedievales de su historieta). Aprovechamos el excursus para agradecerle su generosidad y para anticipar que al cierre del artículo se encuentran como Apéndice sus respuestas.

Almer integral (2016) es un volumen que recopila relatos publicados a lo largo de varios años sobre un caballero de la Mesa Redonda creado por este historietista. Ya en la dedicatoria se vislumbra cierta mirada idealizada de, al
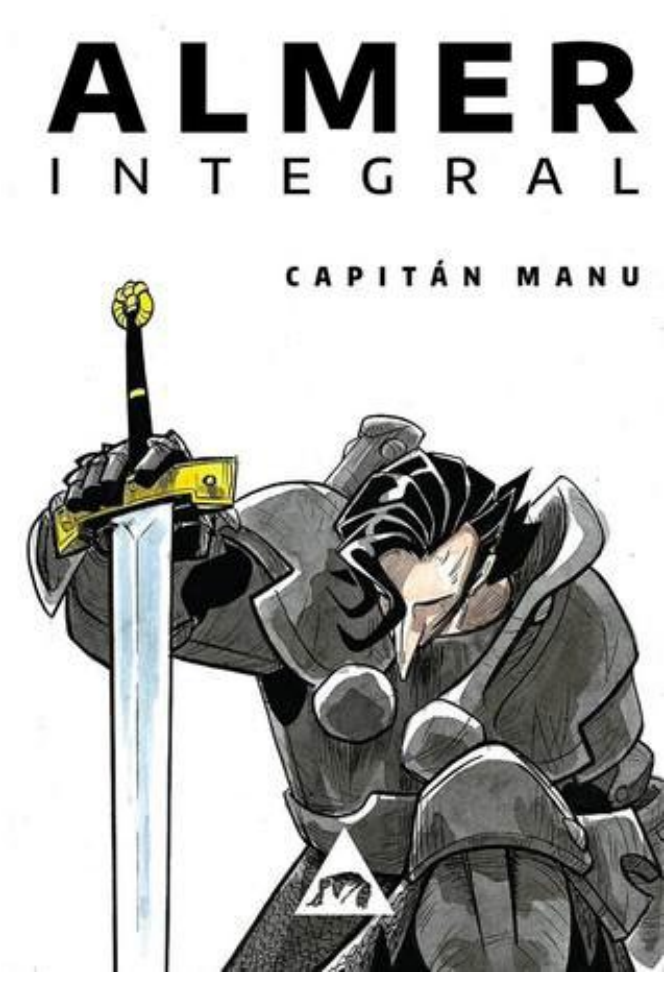

Almer integral, Manuel Loza menos, una imagen de la Edad Media, dado que se destaca la importancia de las «aventuras de ficción» y la necesidad de «más adultos como ellos», es decir, como los protagonistas del cómic. La encargada de presentar cada capítulo, a modo de incipit medieval, es Nyneve o Nínive (también conocida, se nos informa, como Nimué, Vivian, Ninvé, La bruja del lago, La paria o La que mató a Merlín), quien si bien enmarca las aventuras carece de viñeta en sus páginas. ${ }^{4}$ Este personaje introduce a Almer como «el sabio» o «el gentil», y como uno de sus pocos amigos en la corte del rey Arturo. Al margen de esta descripción y adjetivación bastante habitual y esperable para un caballero, aquí resalta una consideración que se colará a través de prácticamente todos los episodios: Almer es «el caballero del pueblo» y «el escudo y espada de los oprimidosı. ${ }^{5}$

El libro recopila diez relatos de extensión variable: «El barquero» (2015, inédito), «El frío y el silencio» (2010), «El orgullo» (201 1), «La luna» (2011), «La confianza» (2012), «La fuerza» (2012), «Ellos» (2012), «El miedo» (2016), «El hambre» (2013), «Marhalt» (2015, inédito).6 Enrique Alcatena se encargó de prologar la edición de 2017, donde refiere que la lectura de Almer lo había remontado a su contacto con las versiones de

\footnotetext{
4. Según Scott McCloud, "a borderless panel can take on a timeless quality» (1994: 102, en cursiva en el original). Este recurso puede contribuir a hacer de la historia de Almer un relato eterno, que trasciende el tiempo y el espacio.

5. En su introducción a Los hechos del rey Arturo y sus nobles caballeros, principal referente artúrico de Loza (ver Apéndice), John Steinbeck explica: «Creo que mi percepción del bien y del mal, mi sentimiento de noblesse oblige, y todas mis reflexiones contra los opresores y a favor de los oprimidos provinieron de ese libro secreton (1977: 10). Steinbeck alude, continuando la cadena hacia atrás, al regalo que su tía le hizo de la Morte d'Arthur de Thomas Malory, según él mismo, primera lectura que lo marcó. En esta línea, en la introducción también se observa una inclinación a caracterizar los personajes, incluso los héroes, como más humanos y con mayores matices, lo que provoca una mayor empatía. Hay que tener en cuenta que en la aventura del inexperto Ewain, temeroso del posible fin de la caballería, el hijo de Morgana espeta: «Si hombres sin linaje pueden medirse con los que han nacido para el mando, la religión, el gobierno, el mundo se derrumbaría en pedazosı) (193).

6. En la colección posterior, Almer definitivo (2017), figuran doce relatos: se omite «El frío y el silencio» y se incorporan, como primer episodio, «El perro»y, cerrando el tomo, «Los otros» y «Una idea». La mayor parte de las aventuras ya habían sido publicadas en distintos números de Panxarama de la editorial Panxa, o en la colección Burlesquitas, de editorial Burlesque.
} 
T. Malory y T. H. White, que no están exentas de matices (observación que acentúa las particularidades del universo artúrico de Capitán Manu):

\begin{abstract}
El primero [Malory], un oscuro noble partidario de los Lancaster durante la Guerra de las Rosas, compuso su obra en prisión [...]. Malory celebraba melancólicamente la era de los caballeros, que la Historia dejaba atrás [...]. Pero el mito muchas veces sobrevive a la realidad y el ciclo artúrico ha inspirado a autores de todas las latitudes desde entonces [de Inglaterra nos lleva a Estados Unidos para, en las páginas venideras, trasladarnos a Sudamérica]. T. H. White, en el siglo XX [...] aborda los viejos romances caballerescos con conmovedora pasión, y donde no faltan el humor, el detalle intimista, la tragedia y la farsa [...]. Nuestro Capitán Manu [...] hace gala del mismo desenfado, del mismo afán entrañable por su material, de la misma impronta emotiva y humanista. Fantasía, sí, pero más cerca del espíritu medieval, del idealismo caballeresco, que de las andanzas del Conan de Howard o el Elric de Moorcock (AD: 4 y 5).?
\end{abstract}

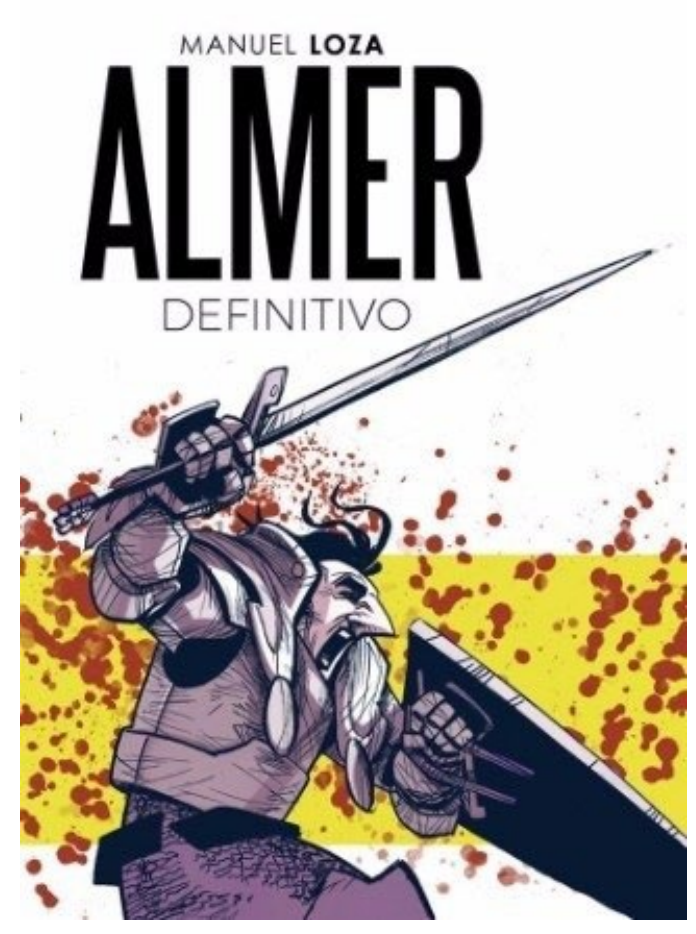

Almer definitivo, Manuel Loza

La estética de la obra es similar a lo largo de los números: las ilustraciones son en blanco y negro, ${ }^{8}$ las viñetas varían de tamaño y el marco es suprimido en algunos casos. ${ }^{9}$ En cuanto al argumento, la premisa general es que, tras ser nombrado caballero, Almer debe alejarse del reino en busca de aventuras. Veremos, a continuación, algunos elementos particulares del universo artúrico de este personaje que, aunque vive en la Edad Media, emana de la Buenos Aires del siglo XXI.

7. Todas las citas se toman de la edición de Almer integral consignada en la bibliografía, y se incluirán a continuación y entre paréntesis las siglas Al seguidas del número de página. En el caso de los episodios que solo se encuentran en Almer definitivo se hará lo propio con las siglas $A D$.

8. «In black and white, the ideas behind the art are communicated more directly. Meaning transcends form. Art approaches language» (McCloud 1994: 192, en cursiva en el original).

9. «The panel acts as a sort of general indicator that time or space is being divided. The durations of that time and the dimensions of that space are defined more by the contents of the panel than by the panel itself. Panel shapes vary considerably though, and while differences of shape don't affect the specific 'meanings' of those panels vis-a-vis time, they can affect the reading experience)' (McCloud 1994: 99, en cursiva y negrita en el original). 


\section{La búsqueda identitaria}

La Edad Media que se construye y que se puede ver en el entramado total se observa ya desde la aventura iniciática, que replica las experiencias inaugurales de copiosos relatos caballerescos medievales. En "El barquero», Almer parte de Camelot para llegar agotado a las Islas Orcadas, fortaleza del duque de Reinhold. La primera persona de la narración nos permite advertir la percepción de la época desde el propio caballero quien, cuando arriba al castillo, describe a la comitiva como la imagen gastada y decadente de la nobleza del reino. A pesar de esta mirada negativa se nos indica que el caballero, hijo de Sir Brastias (guiño, tal vez, al Sir Brastias medieval, que se encuentra también en Steinbeck), reconoce a los nobles que lo reciben como pertenecientes a su mismo estrato social y, por lo tanto, los considera dignos de su confianza. El problema de clase aparece, en efecto, tematizado desde el primer momento y su comprensión y mejor enfoque serán ejes clave para devenir un caballero acabado.

Tradicionalmente, en el roman medieval, la aventura es nodal y lleva al héroe a indagar aspectos de su propia identidad. En Almer, con cada aventura el protagonista va descubriendo quién es $y$, más importante aún, quién quiere ser. La pregunta es qué características y virtudes definen aquí al caballero artúrico. Cuando Almer llega al castillo del duque en "El barquero» y ve la desesperación en la cara de los habitantes, reflexiona: «sabía que estaba por pasar una prueba que definiría mi futuro enterols (Al: 10). El acento en el contraste entre el cansancio y el hambre del caballero errante y la comida, la bebida y el ropaje que lo esperan ofrece una mirada más cruda y realista de la labor caballeresca de la que se puede ver en gran parte de los romans medievales. Los nobles no le ofrecen estos bienes materiales únicamente porque estén siguiendo las reglas de la hospitalidad, sino que buscan que Almer los ayude a solucionar un problema: que se enfrente a un monstruo que se acerca periódicamente a acechar el castillo y que tiene como potencial víctima al estrato nobiliario que domina esas tierras (no al campesinado ni a los viajeros). Los anfitriones de Almer aprovechan la identificación del personaje con su estrato social para presentarle al Barquero como un enemigo común: así, el obispo Killion explica cómo «SU amenaza constante a nuestra forma de vida, la nobleza que hace a la isla de Britania, solo puede acarrear el caos más profundo» (Al: 13)..$^{10}$ Esta impresión de que la clase noble es la garante del orden quedará refutada más adelante, cuando sean los labradores los que defiendan y ayuden a Almer y Sir Gawain en «Ellos».

Comprometido a ayudar a la nobleza que, supuestamente, sirve al rey Arturo, Almer asciende las escaleras que llevan a la torre del castillo para enfrentarse con el monstruo, que llega desde el norte en medio de una tormenta. En la secuencia de imágenes correspondiente, en las tres viñetas de la página izquierda se produce un zoom out en el que vemos a Almer cada

10. Aquí se observan resonancias de Caronte en la figura del barquero, encargado de la transición al mundo infernal en la mitología griega. En El gigante enterrado (2015) de Kazuo Ishiguro ya aparece esta figura, a cargo de la narración y con fuerte presencia en el relato, en un mundo medieval artúrico. 
vez más pequeño, mientras que en las tres viñetas de la página derecha se produce un zoom in que nos acerca cada vez más al monstruo. Se anticipa así el enfrentamiento, pero también el diálogo, que se desarrolla en un escenario caótico de fuerzas naturales desatadas y luz cambiante. Esta secuencia de escenas en tres paneles se replica en muchas oportunidades (como cuando Almer ingresa al castillo o cuando suben las escaleras) y le aporta un dinamismo cinematográfico muy interesante al cómic. El monstruo en sí, un dragón con rasgos de murciélago, está dibujado de manera que resulta atractivo para el lector y lo predispone para leer sus palabras bajo una luz favorable.
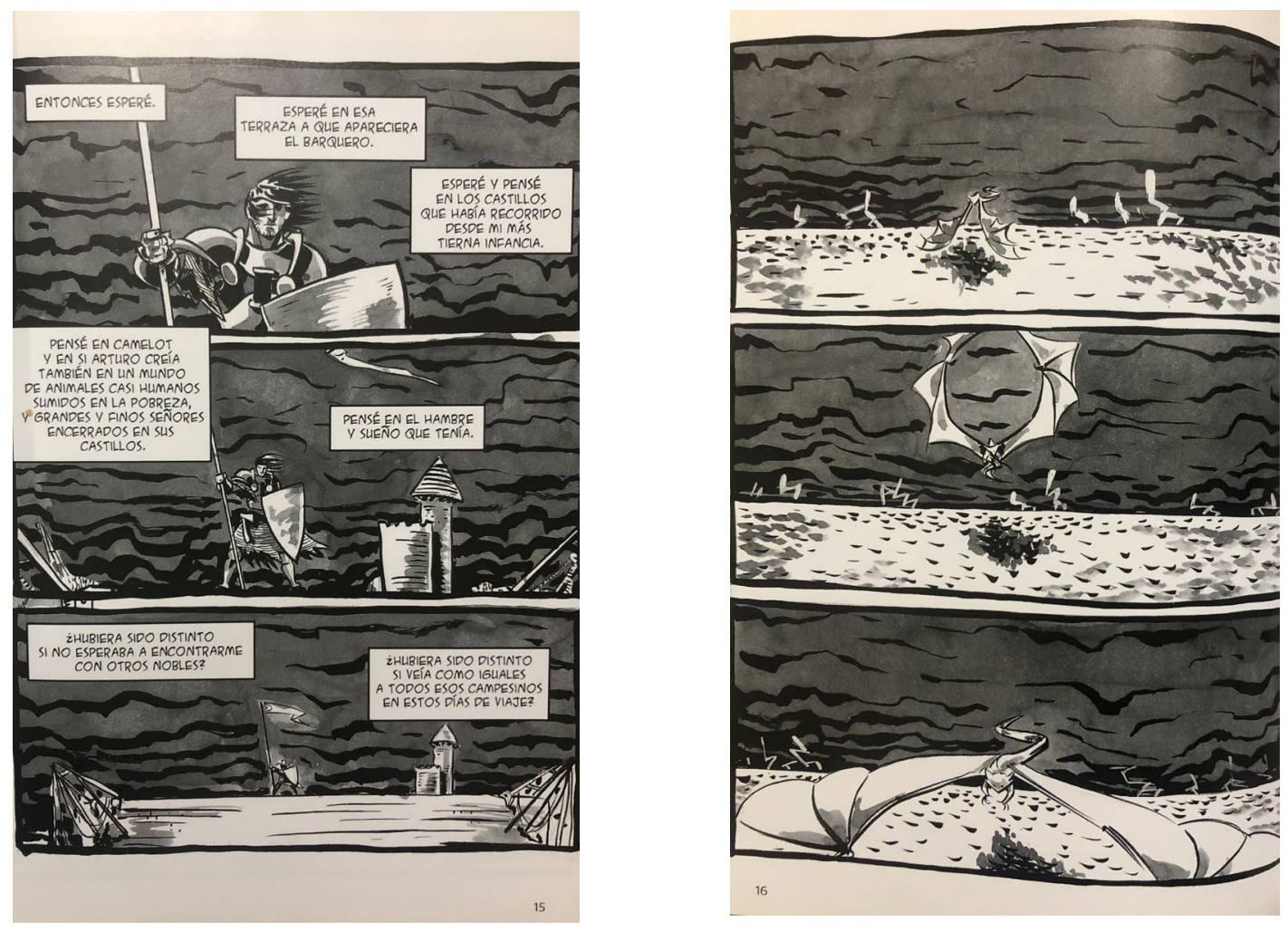

Almer integral, Manuel Loza

Durante la pelea, el Barquero trata a Almer como un niño y, peor aún, le indica: «vas a ser devorado. Y todo por defender al opreson» (Al: 18). En la misma dirección, lo acusa de «violento defensor de los falsos dueños de estas tierrası (Al: 23). Se revela así la verdadera manera en que los anfitriones de Almer pretendían que solucionara su problema: no matando al dragón, sino funcionando como tributo para ser ingerido vivo en lugar de ellos. Esta interpretación de los hechos se ve reforzada por la alusión mitológica que en el nombre de la doncella, Ariadna, remite al mito griego de Teseo y el minotauro. El duque de Reinhold y su corte se revelan así como parásitos que se mantienen con vida gracias al sacrificio ajeno: el de los campesinos, quienes permanecen bajo el yugo de lo que es en la práctica esclavitud, y el de los incontables caballeros a quienes mandan periódicamente a morir bajo las garras del Barquero. A medida que Almer comienza a comprender que ha sido utilizado, algunos elementos gráficos marcan el cambio que se opera en 
su interior, como la secuencia de tres viñetas verticales donde lo que cae no es el dragón, como se esperaría, sino el estandarte.

El ataque verbal incisivo de la criatura encuentra, sin embargo, una resistencia en un aspecto. Almer no permite que el ideal artúrico sea vituperado: donde el Barquero ve un rey que se proclama como superior al resto de los hombres, un monarca hipócrita que jamás se sentó a una mesa como un igual y que no es más que una justificación para que los caballeros se sientan mejores, Almer ve el sueño de la equidad entre los hombres: «Arturo nos habla de eso, de estar al servicio de los olvidados, de los más pobres y vulnerablesı (Al: 20). Con mucha más dignidad que aquella que tienen los nobles traicioneros, la bestia emite sus palabras finales: «Serás el recuerdo de lo grande que pueden ser los hombres cuando dedican su vida al otro» (Al: 33). En esta aventura, Almer encuentra la identidad que adoptará como propia, aquella que irá perfeccionando con el tiempo.

En cuanto al duque de Reinhold y el obispo Killion, queda claro que no están relacionados con el ideal artúrico más que en apariencia: hablan despectivamente de cómo Arturo les seguirá enviando héroes para el sacrificio por su gran soberbia y conversan acerca de cómo recuperar el poder. A sus ojos, el poderío centralizado de Camelot drena a las noblezas locales de su capacidad anterior y debilita el vínculo que establecen con los campesinos. Existe en estos personajes un deseo de recuperar el orden previo de las cosas. La propuesta final que le hacen a Almer va en línea con ese deseo conservador: el duque le ofrece el título de caballero a cambio de que se case con su hija, con el propósito de que las tierras se mantengan entre familias nobles. Almer responde a la oferta con un golpe y un pensamiento que introduce el tema del dormir y del despertar, que será fundamental en la colección: «estaba despiertoı (Al: 41). En el cierre de este episodio, el espabilarse responde a la capacidad de modificar su visión sobre la realidad y sobre su labor y misión caballerescas; ver a los nobles como lo que en verdad son y comprender cuál es su tarea y a quiénes debe defender le otorga una nueva fuerza.

\section{Un anhelo al despertar}

La idea del sueño aparece con recurrencia en los episodios que conforman la historia de Almer. En «El miedo» se parte de un cariz concreto y terrenal, del acto de dormir en sí: la reina Ginebra es adormecida por una bruja que busca eventualmente matarla. Este es un sueño palpable que esconde las intenciones viles de quien intenta perjudicar al reino; es a la vez un sueño real y una pesadilla (metafórica) en ciernes. Almer rescata a la reina de este amodorramiento $y$, en la interacción que sigue entre ellos antes de que el caballero salga en pos de la hechicera, se presenta con claridad otra concepción del vocablo: el sueño en tanto deseo o esperanza, que podemos reconocer de manera emblemática en el discurso «l have a dream» de Martin Luther King. Los personajes no se refieren aquí a cualquier anhelo, 
sino al sueño de Camelot como proyecto de un lugar mejor, de un mundo justo entre iguales. En medio de las vacilaciones y dudas que han aquejado a Almer en esta aventura, su miedo lo ha sumido en un ataque de pánico. En esto se ve muy claramente el aprovechamiento del aspecto psicológico de los personajes, no tan explotado en los relatos medievales pero sí en las versiones modernas. Esta ilusión se presenta como lo único que en verdad interesa: «Señora, mi mente dispersa casi lo olvida... es usted, es Arturo, es el sueño de Camelot lo único que importa» (Al: 125), dice Almer a Ginebra; a lo que ella responde: «No hay protagonistas aquí, solo el sueño de un mundo entre iguales, querido Almenı (Al: 125). Este sueño, este deseo de un mundo más equitativo, es lo que persigue y defiende el personaje, es lo que lo caracteriza, lo que le da su nombre, lo que lo lleva a enfrentarse a la bruja y vencer su miedo: «El sueño de Camelot es la ausencia de escalas [...]. Todos trabajamos en pos del sueño» (Al: 128).

La apuesta se complejiza en «El hambre», que continúa la persecución de la hechicera iniciada en el episodio anterior. En esta nueva aventura Almer pelea junto a un caballero proveniente de una tierra desconocida, el joven Érica, protagonista de una serie llamada El Ombligo, creada por El Santa. En este crossover que une a Almer con un caballero que recorre universos oníricos, el acto de soñar se suma al de dormir y se distingue del anhelo. La cuestión se problematiza a partir de las ganas de Érica de tomar una siesta; en su mente el joven oye las palabras de su maestro, quien le dice: «Ni los soldados ni los guerreros son capaces de descansar. Solo los hombres sueñan. Deja tu armadura si pretendes dormirı (Al: 133). Pareciera que tanto el reposo como las ensoñaciones les están vedadas a los caballeros como él (y como Almer). En cambio, lo único que les queda (como demostrará el resto del episodio) es la realidad, el sueño en tanto afán o esperanza. ${ }^{11}$

La magia de su maestro lo transporta a un universo paralelo, nuevo y distinto: el reino de Arturo. Cae (literalmente) en las catacumbas del castillo en medio de la huida de la bruja a la que persigue Almer. Su apreciación de la situación es equivocada y se enfrenta al caballero del pueblo para defender a la que, cree, es una mujer inocente. Cuando descubre su error se une a Almer en la caza de quien se revela súcubo, heraldo de un ser llamado «el Macrófago», el cual se acerca «desde el vacío entre las estrellas, recorriendo distancias de pesadilla» (Al: 146, nuestra cursiva) para destruir Camelot pues "él es el ocaso del mundo, de todos los mundosı (Al: 147). El combate que sigue es feroz, ya que la bruja tiene el poder de reanimar a los muertos; de despertarlos de su eterno dormir, dando así un nuevo matiz al asunto. Semejante hecho despierta la cólera de Almer, ${ }^{12}$ quien se pregunta: "¿2Pero qué clase de locura es esta? ¿Qué sueño surgido del espanto podría abrir las tumbas de Camelot

\footnotetext{
11. La dicotomía sueño/vigilia entreverada con el par pesadilla/realidad ya aparece en «La luna», episodio en el que Sir Gorlick, duque de Loth, es perseguido por una bestia que ataca de noche, cuando los humanos duermen; en esas circunstancias fueron asesinados su familia y sus amigos. No obstante, más adelante descubrimos que, en verdad, Sir Gorlick está maldito y se convierte en hombre lobo al salir la luna: fue él mismo quien acabó con sus allegados y quien se autoinflingía las heridas.

12. Podríamos pensar que ante dicha situación Almer siente miedo o desesperanza, pero el primer plano de su rostro no deja dudas de que no son estos sentimientos los que lo embargan sino un profundo enojo, un rechazo e, incluso, desprecio ante tan malévola acción.
} 
y soltar a sus ocupantes como bestias?») (Al: 143). Se instala así, una vez más, la concepción de sueño en tanto anhelo, esta vez a partir del deseo de un enemigo de destruir el mundo artúrico, que se presenta como opuesto al sueño de Camelot, el que defienden Almer y todos los caballeros de la Mesa Redonda.
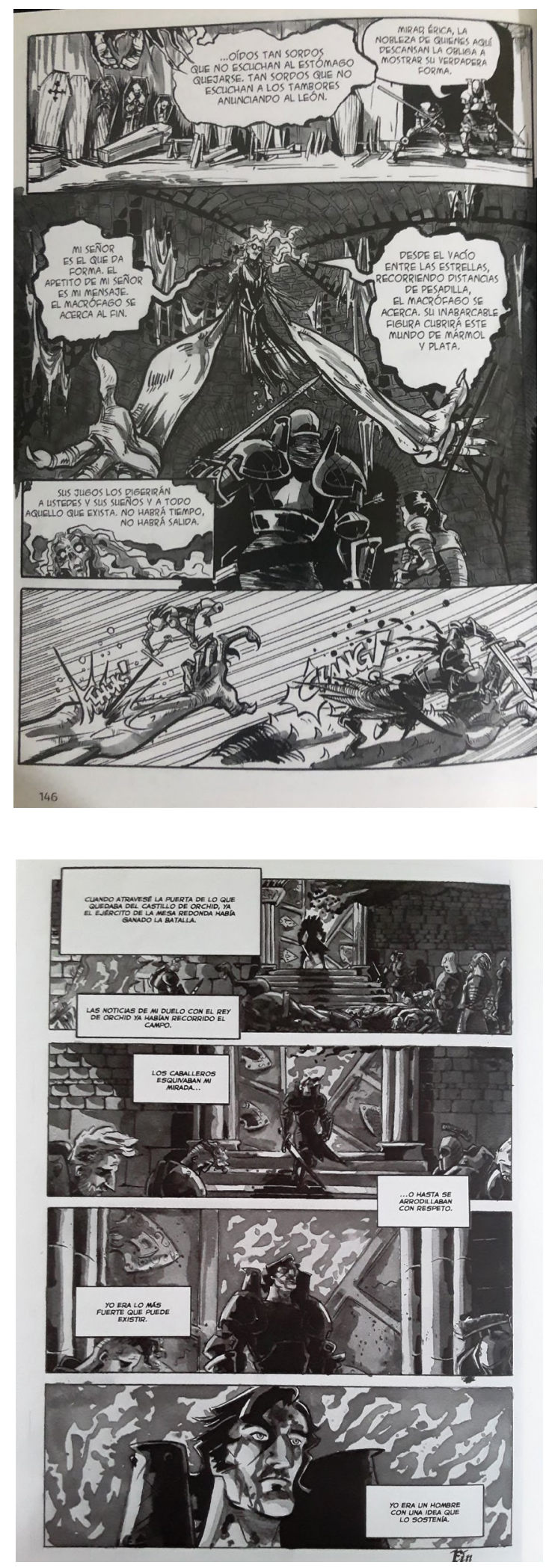

Almer integral, Manuel Loza Este uso se reitera en la amenaza de la bruja: "SSus jugos [del Macrófago] los digerirán a ustedes y sus sueños y a todo aquello que exista. No habrá tiempo, no habrá salida» (Al: 146), y en la victoria final de Almer y Érica, cuando aquel mata al súcubo: «iMuere en nombre de Arturo!... y por el sueño de Camelot y de todos sus héroes» (Al: 150). Finalmente, el episodio concluye con el regreso de Érica a su mundo tras tropezar con una piedra: desaparece de Camelot y se corporiza sentado en su propio universo.

Esta idea continúa desarrollándose en las tres últimas aventuras que incluye Almer definitivo. El protagonista viaja a la isla de Erin para ayudar a su rey contra Baudemagus, un usurpador, y los vikingos, sus cómplices. Los dos últimos relatos escenifican la guerra en la que caballeros de Camelot pelean junto a los irlandeses. La violencia, la muerte y el dolor que viven son expresados con contundente claridad por Nyneve: «No sé... La guerra es una mierda») ( $A D$ : 162). En esta secuencia, Almer tiene dos enfrentamientos de gran impacto: en el primero, derrota y mata en combate a Bragan el gentil, que era el campeón de los desposeídos en su tierra. Su muerte, de hecho, causa a Almer gran tristeza. El segundo se desarrolla en el último episodio, cuando la guerra está llegando a su fin (se nota en la estética utilizada: predominan los grises y el negro); aquí, Almer se enfrenta en un duelo con el propio señor del castillo de Orchid. Este se mofa de Almer y lo humilla pues descree de Arturo y de sus uideas decadentes» (AD: 175) pero es vencido por el protagonista. Esta victoria final no es solo un triunfo en el plano de las armas ya que, más aún. Almer se ve 
fortalecido por su convicción en Arturo y en la posibilidad de un mundo más justo. Hacia la conclusión del recorrido que nos propone Almer definitivo, él ya no es un caballero novel y Camelot no es solo un sueño. La página que cierra el volumen ofrece un zoom in progresivo en cada viñeta (que nos recuerda al zoom out que habíamos visto en «El barquero») hasta mostrar en la viñeta final un primer plano de Almer diciendo: "Yo era un hombre con una idea que lo sostenía» (AD: 176). El sueño se ha transformado ahora en ideal realizable y, por ende, en un sostén político e ideológico del caballero.

\section{Amor y armas: la amistad como eje}

En términos temáticos, el roman medieval se construye principalmente sobre la imbricación entre amor y armas: el caballero debe vencer en el combate para ser merecedor de su dama. ${ }^{13}$ Algo de esto se percibe en Almer pero solo marginalmente: Ios trabajadores pugilistas vencidos son asistidos por quienes asumimos son sus mujeres en "La fuerza»; Gawain conserva su fama de galán empedernido: "La voracidad con la que se enfrenta a la vida es impresionante: mujeres, placeres, risas y aventuras parecen nunca saciarlo» (AD: 165), lo describe Almer en «Los otros». Por su parte, el joven caballero Érica tiene como objetivo en el episodio referido más arriba volver con su amada Lucía. Incluso el acercamiento de Nyneve al conde Romulich en «La confianza» puede ser entendido inicialmente como un interés romántico (aunque luego comprendemos que es parte de la estratagema de la bruja para vencerlo). Sin embargo, en este aspecto el protagonista de los relatos se aleja de las expectativas del género.

En «El barquero» Almer percibe el interés de la hija del conde Reinhold, que le es ofrecida más tarde en pos de una alianza cuando el protagonista vence al monstruo que acechaba las Islas Orcadas. La respuesta de Almer es indicativa de su postura, y esta aventura lo ayuda a definirla: el entonces caballero novel rechaza la unión y toda conexión con aquel soberbio noble, que quiere recuperar el poder y un antiguo orden basado en la esclavitud de los campesinos, para adoptar la tarea de proteger la justicia y la equidad. De la misma manera, no atiende el pedido de la doncella Ariadna, quien le ruega que la lleve con él, y la deja atrás en su propio laberinto de mentiras y engaños. La elección de Almer en la aventura inicial da la pauta de la misión que ha emprendido y que lo definirá a lo largo de los relatos: su interés no es al amor, sino la defensa del ideal artúrico.

Lejos de manifestar deseos eróticos o amorosos, al caballero del pueblo se lo asocia con un importante personaje femenino, la bruja Nyneve. A pesar de que con frecuencia emplean el vocablo «amigo» o «amiga» para referirse al otro - «son pocos los amigos que tengo en la corte del rey Arturo. Entre

13. «Aunque más que una representación de lo real o de una ficción social, el tratamiento del amor en Chrétien y sus sucesores, hasta el umbral de la época moderna, contrae en el discurso un vínculo indisociable con el combate: sufrimiento caballeresco y placer erótico, hombre y mujer, de tal manera que el tiempo del relato es, siempre diferido, el tiempo de un deseo» (Zumthor, 2016 [1978]: 16). 
ellos, el más grande y caro a mi corazón es Almer» (Al: 6), dice Nyneve; «mi mejor amiga. La persona en quien más confío en el mundo» (Al: 116), en boca de Almer- el término no es empleado con el sentido medieval, según el cual amigo/a es el/la amante. La relación que une al caballero del pueblo y a la bruja no implica amor romántico sino una amistad en un sentido más contemporáneo: es un vínculo de afecto mutuo, puro y desinteresado. El aprecio que se tienen se percibe en los elogios de Nyneve cuando cumple el rol de presentar cada episodio y también hacia el interior del relato, por ejemplo en "La luna»y en "La confianza», donde Nyneve aparece como personaje. En el primero convoca a Almer con el pensamiento para que la ayude a salvar a otro caballero de la Mesa Redonda, y dos veces en la misma aventura le recuerda a Almer que es su amiga y que está para cuidarlo. En el episodio siguiente, la muchacha es rescatada de las garras de Romulich por el caballero. Cariño, cuidado, confianza: esas son las bases de su unión, y lo dejan claro en sus parlamentos: «En un mundo de cazadores y presas, nada es tan bello y fiel como el hombro de un amigon, dice Nyneve (Al: 62); "aquella bruja compañera, amiga y confidente», la describe Almer (AD: 166). Esta concepción es coherente con la importancia dada por los caballeros a la camaradería, que puede entenderse como el cuidado del otro por sobre el acrecentamiento del ego en el cumplimiento de las aventuras.

\section{La Dama del Lago y el sobrino de Arturo}

El universo de Almer comparte características con otros escenarios artúricos, ya medievales, ya contemporáneos. ${ }^{14}$ La geografía que recorre el caballero es similar a la que describen muchas fuentes medievales: Almer va desde Camelot hasta las Islas Orcadas y visita la Bretaña francesa e Irlanda. Lo exótico se asocia con el este, al igual que en muchos textos medievales, como queda claro en "La confianza», donde Nyneve y Almer se dirigen al urincón más oscuro de los Cárpatosı (Al: 72). Constitutivo de la leyenda artúrica es también el elemento maravilloso, que no se omite en las aventuras de Almer: pueblan sus relatos un gigante, el Marhalt de la aventura homónima; monstruos metamorfoseados en humanos, como Sir Gorlick (hombre lobo) y Romulich (vampiro), o el súcubo que adopta la forma de bruja para poder matar a Ginebra; y animales fantásticos, como un kelpi, uun ser monstruoso que devora niños, que duerme en aguas oscuras y que carga con el rostro de un equino» (Al: 55) o el mismo Barquero, un dragón con función de psicopompo.

Dentro del elenco de personajes que se cruza en sus viajes, cobran gran protagonismo «ellos», los campesinos y trabajadores anónimos a quienes defiende Almer; esto resulta una particularidad novedosa respecto de los textos medievales, en los que los «villanos» suelen ser menospreciados, ridiculizados o incluso considerados malvados e ignorantes. No obstante, la

14. En la entrevista, Manuel Loza afirma: «En mi cabeza Almer vive entre escenas de la película Excalibur y la mayoría de los personajes clásicos del ciclo artúrico están a partir de la interpretación que les dio John Steinbeck»». 
importancia de este grupo en la serie de Loza responde al interés principal del protagonista, es decir, transformarse en su defensor, como máxima aspiración de la caballería. Más allá de esta incorporación al reparto artúrico se hallan nombres que resultan familiares para cualquier conocedor de la leyenda: Sir Brastias, el padre de Almer, es uno de los caballeros, del duque de Cornwall primero y de Arturo después, en La Morte Darthure de Malory y en Los Hechos del rey Arturo y sus Nobles Caballeros, de Steinbeck; el gigante Marhalt recuerda al capítulo "Gawain, Ewain, Marhalt» de Steinbeck y al Morholt/ Moroldo de la materia tristaniana, en especial por habitar en Irlanda, donde Almer y sus compañeros se dirigen en busca del rey Mark; Baudemagus, que en El caballero de la carreta de Chrétien de Troyes y en el ciclo de la vulgata es el padre de Meleagante, mientras que en La Morte Darthure de Malory es uno más de los caballeros de la Mesa Redonda, es presentado como el usurpador del trono de Irlanda y aliado con los vikingos. De todos estos, aquellos que ocupan un rol central, tanto en las aventuras como en el círculo afectivo de Almer, son Sir Gawain y Nyneve.

Por un lado, contamos con el sobrino del rey Arturo y principal caballero de la Mesa Redonda; al igual que en la mayoría de las fuentes medievales se destaca entre los demás por su virtud guerrera y su cortesía. ${ }^{15}$ La descripción que hace Almer en «Los otros» es significativa: "Gawain se mueve por el mundo como si fuera inmortal, su carcajada nos llena de bravura con solo escucharla» (AD: 165). Empero, sus palabras y acciones evidencian que su grandeza viene acompañada de cierta soberbia, que demuestra que es tan humano y falible como cualquier otro hombre. En «La fuerza», por ejemplo, no es capaz de vencer al Griego, un pugilista profesional, y termina siendo rescatado de una tremenda golpiza en el cuadrilátero por su amigo Almer. Esto lo pone en igualdad de condiciones con los villanos y trabajadores que fueron derrotados con anterioridad por el mismo contrincante. En «Ellos», además, tanto Gawain como Almer son desmontados por Gorodoc, quien busca venganza por la muerte de su hermano, y es la gente del pueblo la que ataca y vence al enemigo, con lo cual una vez más Gawain demuestra que su gallardía no es superior al esfuerzo y la fortaleza de la clase popular. Esto no impide que tenga una actitud condescendiente con ellos, como se entrevé en los apelativos que emplea para nombrarlos («la chusma», Al: 94, «los rústicos», Al: 104) o en su afirmación al arribar a las tierras del norte: «No es fácil visitarte [a Almer] y salir de la ciudad de oro y mármol para venir a tu paraíso de barro y bosta»

15. El personaje de Gawain (seguimos la grafía de Almer) es uno de los más antiguos de la leyenda artúrica, muy vinculado a la rama celta de la leyenda. En los romans de Chrétien de Troyes ocupa un rol marginal, ya sea como contrapunto del héroe principal o como caballero modélico con el cual se miden los demás; recién en la segunda parte del inconcluso Cuento del grial cobra prominencia. Sin embargo, el personaje adquiere mayor protagonismo en una serie de romans franceses en verso del siglo XIII, en los que su imagen es tratada de forma burlona o paródica. En los romans franceses en prosa también es considerado como uno de los mejores caballeros de la Mesa Redonda, con excepción del Tristán en prosa, donde varias fechorías manchan su nombre. En la tradición inglesa, en cambio, Gawain es el modelo indiscutido de cortesía en los romances en inglés medio, entre los cuales Sir Gawain y el Caballero Verde es, probablemente, el más conocido (popularidad potenciada, actualmente, por la salida del film de David Lowery en 2021). En la obra de Malory, cuyas fuentes incluyen el Tristán en prosa, la imagen del sobrino de Arturo está mucho más matizada y el caballero, en su afán por defender el honor de su familia, incurre en varias acciones reprobables. 
(Al: 104). En el esquema trazado de aprendizaje caballeresco podría pensarse que sus aventuras pertenecen aún a episodios intermedios que enseñan que el crecimiento es gradual y no repentino.

De esta manera, el personaje de Gawain contrasta con el protagonista: el primero responde al paradigma del caballero apegado a los valores cortesanos, mientras que el segundo es el paladín de los más débiles, cuya compañía prefiere a la de otros nobles. Almer nota la diferencia entre ambos y siente que no lo favorece, aunque aquí se resalta su humildad: "Ambos sabemos que no estoy a su altura, él es un héroe. Y yo un pobre niño que juega con espadas» (Al: 1 16), dice en «El miedo». En la entrevista al dibujante y guionista, Manuel Loza afirma: "Gawain es el caballero engreído y canchero que mejor dinámica vincular puede tener con el pibe sensible y timidón como Almer. Son dos personajes que se quieren mucho pero no podrían ser más distintos, y los diálogos resultantes están buenísimos para escribinı. La contraposición entre los dos caballeros recuerda la similar relación entre Gawain y Perceval en el inconcluso Cuento del grial, solo que el galés rústico es reemplazado aquí por el protector de los oprimidos. ¿Sería posible pensar en Almer como una reescritura del roman de Chrétien? Ciertamente comparten elementos que enriquecen la lectura y abren nuevas puertas interpretativas, pero una lectura que se limitara a compararlos sería demasiado estrecha.

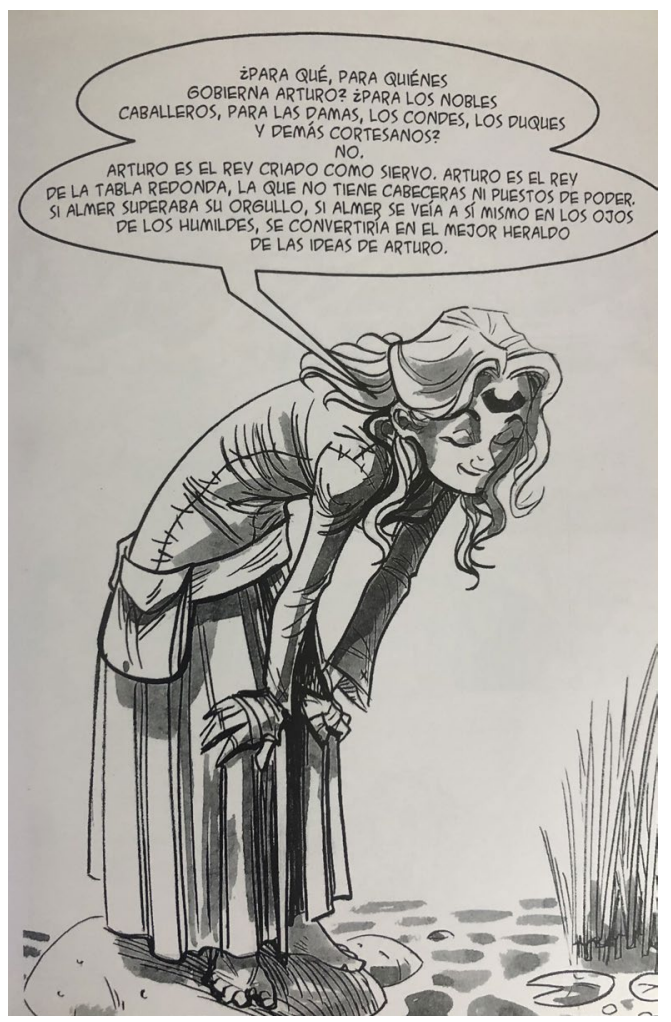

Almer integral, Manuel Loza

Por otro lado, la Nyneve de Almer lucha contra la fama de hechicera seductora y perversa que hereda de la tradición, no solo medieval sino, también, de reescrituras posteriores.16 Aquí la muchacha se distingue por su amistad incondicional con el protagonista, a quien acompaña en varias de sus aventuras, y por la sabiduría y perspicacia de sus reflexiones al presentar los episodios, por la sencillez con que la que se la caracteriza en las ilustraciones, por la sonrisa afable con la que da inicio a la mayoría de los relatos y por la resolución que muestra en otros. Se la distingue, asimismo, por la bravura con que se enfrenta a sus enemigos: en «La confianza» intenta derrotar sola al conde Romulich y en «Los otros» es una guerrera más en la batalla contra los opresores, y una combatiente de temer: «A mi lado Nyneve es un monstruo de barro y sangre [...]. Hoy Nyneve es el diablo. Hoy le temo», dice Almer (AD: 166). La profundidad

\footnotetext{
16. Véase, por ejemplo, la versión del personaje que presenta Lord Alfred Tennyson en sus muy influyentes Idylls of the King, publicados entre 1859 y 1885. La que aquí recibe el nombre de Vivien se construye como una antagonista de Arturo que, junto con otros enemigos como el rey Mark, no busca más que la desgracia del reino. Con astucia y mentiras, la doncella logra finalmente seducir y capturar para siempre a Merlín con su propio hechizo en el idilio «Merlin and Vivien».
} 
que adquiere este personaje se podría explicar por el favoritismo que siente el autor por ella: «[...] creo que Nyneve es un personaje espejo donde se ve reflejada la ideología del lector: hay quienes leen el ciclo artúrico y ven en Nyneve el arquetipo de la mujer seductora e histérica que manipuló a ese pobre viejito y hay quienes, como Steinbeck, ven en Nyneve a una piba que escapó como pudo al acoso de un tipo increíblemente poderoso y la condena social (y mágica, claro) que ello le trajor.

En suma, los dos personajes de la materia artúrica que tienen mayor presencia en Almer funcionan como contraste entre los valores caballerescos tradicionales y los erigidos por el cómic, en un caso, y como complemento y revalorización de una hechicera que pasa a ocupar un lugar central y diverso al que la leyenda le otorgaba, en otro.

\section{El bestiario de Almer}

Al igual que en muchos otros momentos históricos, los animales aparecen en los relatos medievales vinculados con la otredad y la naturaleza. Son seres vivos que oponen al héroe con aquello que no es humano y que no pertenece, 0 que está al borde de no pertenecer, al espacio de la civilización. En los relatos de Manuel Loza, Almer interactúa con monstruos e híbridos que lo enfrentan con distintos dilemas, aunque estos concurren con animales domésticos que no por ser más familiares resultan menos complejos.

Ya vimos más arriba la importancia del diálogo con el Barquero, un animal fantástico y parlante que gracias a su carácter no humano puede colocarse como un observador privilegiado del universo medieval. Como buen caballero artúrico, Almer debe seguir afrontando en varios momentos seres que pertenecen al terreno de lo monstruoso, cuya identidad es inquietante y liminal. El monstruo que lo ataca en «El frío y el silencio», durante su primer invierno como caballero, es un ejemplo casi literal de estas características: una presencia maligna indefinida, que habita el territorio desolado y marginal del camino (espacio entre espacios) nevado (y, por ende, inhóspito). El ser sale, además, del interior de un cadáver, con lo cual refuerza su cualidad de abyecto: ni vivo, ni muerto; en ningún lugar reconocible y en medio de la naturaleza, en las antípodas del mundo habitado, en su expresión más hostil. En la tónica de la importancia dada a lo colectivo y al otro se recalca que el frío y el silencio hacen que duelan más las heridas.

Otro engendro que comparte algunas de estas características, pero que está más conectado con el tema de la animalidad, es el kelpi, espíritu perteneciente al folklore escocés que se alimenta de carne humana. En «El orgullo», el kelpi habita una ciénaga, sitio profundamente liminal que alberga monstruos en muchas de las más antiguas tradiciones medievales (como sucede, podemos recordar, en Beowulf). Antes de enfrentarlo, Almer rechaza la hospitalidad de una anciana que habita una de las últimas casas antes del pantano, y que, por su aspecto tétrico, se asemeja a una parca. Mucho más 
turbadores son la figura del kelpi y el combate que se desarrolla: el monstruo tiene cuerpo de hombre pero rostro equino, y durante toda la pelea los colores blanco y negro se invierten en el fondo y en los globos de diálogo, generando la idea de un espacio nocturno o subacuático. El hecho de que el híbrido tenga cabeza equina resulta inquietante en dos niveles: por un lado, el caballo es un animal domesticado y herbívoro, que debería pertenecer al espacio de la civilización; por el otro, posee una carga semántica importante como principal atributo, símbolo y en algunos casos fiel compañero del caballero medieval. ${ }^{17}$ Aquí ambas expectativas se subvierten y el kelpi se presenta como un contrincante temible, caníbal en sus facetas humana y animal, que es igualmente vencido. Agotado por la pelea y cubierto de barro, Almer regresa a la casa de la anciana y, a pesar de que ahora es su apariencia la que resulta ligeramente monstruosa, acepta la hospitalidad que por orgullo había rechazado al comienzo. Como dicen los versos escritos por Bilbo en relación a Aragorn, el montaraz que es, en realidad, heredero del trono de Gondor en El señor de los anillos, de J. R. R. Tolkien: «All that is gold does not glitter / Not all those who wander are lost» (2001 [1954]: 167). ${ }^{18}$

Además de interactuar con sus caballos, que lo acompañan en silencio durante sus aventuras, Almer se vincula con otro animal domesticado. En «El perro», que se incorpora como precuela en Almer definitivo, el héroe, que todavía no es un caballero, dice haber encontrado un animal fascinante, distinto de todos los que había visto. Se trata de un can viejo, feo, gordo y sin ningún pedigree reconocible, a quien decide hacer su compañero de andanzas a pesar de que no se parece en nada a los animales que suelen acompañar a los caballeros. Durante el episodio, el perro se muestra completamente incompetente en el aspecto práctico: no puede mantener el ritmo, duerme profundamente y, cuando son atacados por un oso (animal salvaje por excelencia) ${ }^{19}$ durante la noche, no solo omite defender a Almer sino que ni siquiera se despierta para dar la alarma, antes ni durante la pelea. Enojado, el caballero pretende castigarlo pero descubre la increíble habilidad del animal, que se mantiene oculta hasta el final del episodio. En el castillo de Beloc, Almer y su perro visitan a un noble cuyas hijas le muestran sus elegantes galgos, apropiados para una de las principales actividades del ocio de la nobleza medieval, la caza. ${ }^{20}$ Ya se percibe una distancia entre los valores de la nobleza y unos valores otros, encarnados por Almer y, en este caso, el perro cuya habilidad asombrosa consiste en poder sonreír. Este animal no tiene

17. «La sociedad feudal es una sociedad del caballo. Por lo menos en lo que atañe a la clase aristocrática. Las canciones de gesta y los romans de caballería dan de este animal una imagen valorada, a menudo idealizada, que señala el fortísimo vínculo que une al señor o al caballero con su montura» (Pastoureau, 2011: 101, nuestra traducción).

18. Algo similar sucede con los otros híbridos, ya mencionados, que debe enfrentar Almer en sus aventuras: el muy hospitalario conde Romulich que se revela como un vampiro y el caballero aterrado que resulta ser un hombre lobo.

19. Pastoureau lo define, dentro de la tradición medieval, como un animal extremadamente peligroso, tanto por su cualidad salvaje y violenta como por el hecho de que se asemeja en algunos rasgos al hombre (e.g. su habilidad para andar erguido). En la literatura patrística y carolingia se encuentra a veces, además, asociado a designios demoníacos (2011: 63 y 64).

20. La imaginería del galgo puede apreciarse en el ciclo de tapices, hoy conocidos como «La dama y el unicornion, realizados en torno al 1500. 
características fantásticas, no proviene de familias legendarias ni sirve para la caza, mas tiene una cualidad única que lo asocia con la alegría y la felicidad, y por eso es perfecto para Almer. En el episodio titulado "Una idea», puede verse que la silueta canina aparece en el escudo del protagonista, en lugar del usual león de los relatos de caballería medievales:21 como el barquero, pero simplemente sonriendo y sin hablar, el perro lo ayuda a configurar su identidad.

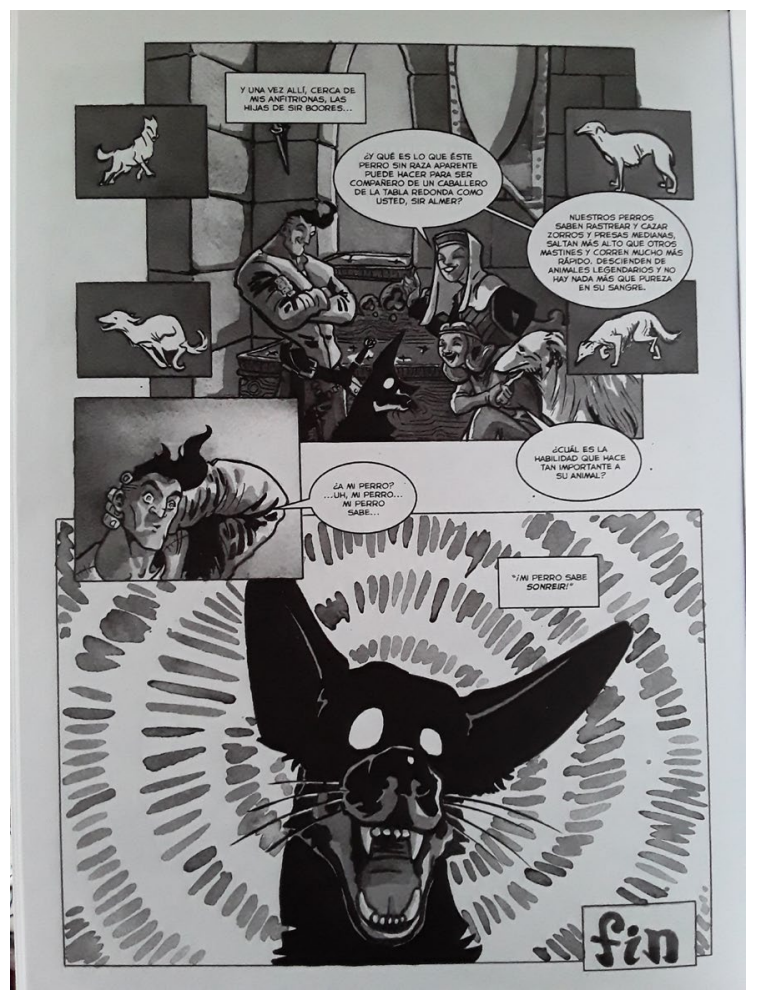

Almer integral, Manuel Loza

\section{Conclusión: el caballero del conurbano ${ }^{22}$}

Como antesala de «El orgullo», Nyneve se pregunta para quiénes gobierna Arturo. Ante este interrogante se responde que Arturo es un rey criado como siervo y hace hincapié en el elemento de la Mesa Redonda, sin cabecera ni puestos de poder. Asimismo, aquí queda claro que el deber de Almer es superar su orgullo y verse a sí mismo en los ojos de los humildes. La dedicación a combatir seres monstruosos, que se recalca luego de la aventura en la ciénaga, responde a que perturban a los vasallos más olvidados. Promediando la empresa, se insiste en que antes de Arturo nadie había prestado servicio a los más humildes y que los reyes solo batallaban entre sí. La cercanía con el pueblo queda patente en las palabras de la anciana, que le dice: «dispuesto a ensuciarte las botas con la misma mugre que pise el más miserable de

21. «A fines del siglo XIII, en toda Europa occidental, todo héroe literario debe tener un león como figura heráldica» (Pastoureau, 2013: 56).

22. Se conoce como conurbano bonaerense al área compuesta por los municipios pertenecientes a la Provincia de Buenos Aires que rodean la Ciudad Autónoma de Buenos Aires (anteriormente denominada Capital Federal). 
nosotrosı (Al: 54), y del pastor de toros: «noble salvador de los olvidadosı (Al: 55), ambas figuras relativamente monstruosas desde lo visual.

En un estadio claramente posterior de asimilación de las virtudes, en «La confianza» el protagonista se presenta a sí mismo ante el conde Romulich como «Sir Almer, caballero de la tabla redonda, guardián de las marcas del norte y protector de pobres y oprimidos» (Al: 76). Luego, en el cierre de «La fuerzaı Almer le explica a Gawain que si hubiese observado a quienes habían sido vencidos por el Griego se habría dado cuenta de que no tenía posibilidad de vencer. Los contrincantes anteriores eran un constructor, un hachero, un herrero, un carpintero y un barquero, es decir, todos trabajadores del pueblo que se dedican a sus tareas desde el alba al anochecer. La lección que Almer le imparte al engreído Gawain es que nunca deben dudar de la fuerza de los trabajadores. A esta altura el protagonista ya aprendió la relevancia del pueblo trabajador, que va a volverse patente en el momento en que los campesinos le salven la vida. El aprendizaje progresivo se extiende hacia Gawain en «Ellos». Cuando el danés Gorodoc quiere asesinar a Almer, su amigo lo defiende y reprende: «Eso te enseñará a buscar el silencio cada vez que tu sucia boca busque ofender al hombre que nos enseñó a ser iguales y a buscar el bienestar del prójimo»' (Al: 105). Estos y otros comentarios de los personajes, así como su accionar, revelan cómo se va tejiendo una red entre los relatos y cómo su disposición y orden van cobrando sentido. En esta misma aventura se destaca que la fuerza del campesinado proviene de vivir durante años como iguales y sin jerarquías.

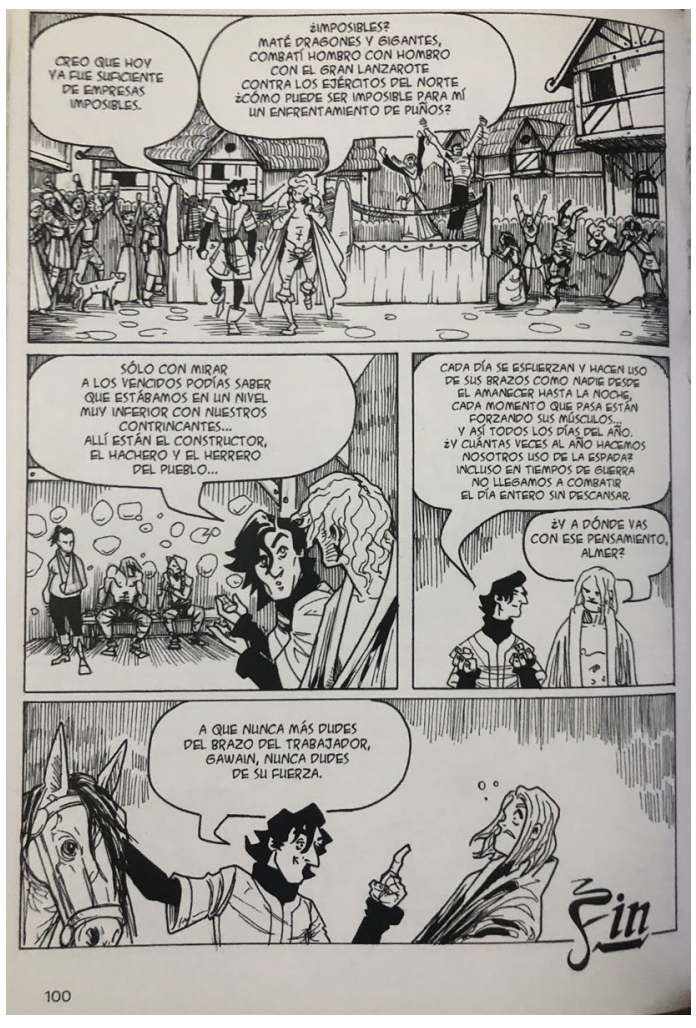

Almer integral, Manuel Loza
El camino no termina ahí; aún quedan desafíos a pesar de la consagración. Frente a los ataques de pánico que Almer padece en "El miedo», donde se enfatiza que el mayor enemigo es uno mismo y se problematiza la autoestima del personaje, Ginebra le dice, como ya apuntamos, que no hay protagonistas sino solo el sueño de un mundo entre iguales. Finalmente, Almer se agota de dudar de sí mismo y de las amistades que lo rodean y, tras ser acusado de ególatra por la bruja a la que perseguía, comprende que verse como un inferior ante pares es otra cara de la debilidad. En "La luna», de hecho, se destaca la importancia de enfrentar y expresar las penas antes que esconderlas, instrucción que se condice con las lecciones de «El miedo» para combatir la ansiedad, la fobia y la soledad.

Cuando Almer decide prestar ayuda a los nobles en su primera aventura, «El barquero», le dice al duque: «todo sea por 
defender a los nobles que estén al servicio de Arturoı. En el instante previo a la llegada del monstruo, ya como narrador y meditando de manera retrospectiva, se muestra reflexivo: "żHubiera sido distinto si veía como iguales a todos esos campesinos en estos días de viaje?») (Al: 14 y 15). El progreso del caballero en el logro de adoptar al pueblo como bandera se ve en las distintas historietas. Ya en «El hambre», donde se indica que el caballero aprendió y creció con cada aventura, Almer mantiene una conversación con Érica luego de la batalla: «Elegí ser nombrado el defensor de los pobres de Camelot, de aquellos que no tienen voz ni voto en un mundo que los ignora... es una lucha constante, que va desde un dragón que los amenace hasta el plato de comida que les falten (Al: 151). Las labores de la caballería se expanden y lo fundamental es el destinatario social de su accionar (que, por supuesto, tampoco se restringe a las damiselas de noble cuna). Almer declara que se sabe protegido por su convicción en pos de un mundo nuevo, de justicia para todos (aquí resuena el Arturo de los «años Kennedy»), movido por el amor a los que representa. Esta vez ubicado del lado del maestro o consejero, nuestro protagonista recomienda: «Nunca dudes de la voz de los desposeídos, pues en ella está la fuerza que nos mueve y nos hace resistir cualquier embate. Como la justicia de Camelot, a donde vayas te acompañaránı (Al: 152).

En «Los otros» Almer se enfrenta con un caballero desconocido y termina por matarlo. Más tarde, Nyneve le revela que se trataba de su equivalente en una tierra otra, un campeón de los desposeídos. La reflexión que cierra el episodio es elocuente: «los otros somos nosotros», últimas palabras del caballero vencido que Nyneve y Almer adoptan como propias (AD: 169 y 170). Como se explicita en "Una idea», los caballeros artúricos deben pelear por un ideal más que por un hombre o por una recompensa. La referencia en el subtítulo al conurbano bonaerense, además de remitir al comentario que Manuel Loza hace en la entrevista, opera en esta dirección: el verdadero caballero hic et nunc, al margen de las particularidades que encarne, se encargaría de defender y acompañar a un sector históricamente relegado en términos de partidas económicas y recursos en contraste con la capital, tan cercana espacialmente. Construcciones de héroes como las de Superman: hijo rojo (2003) o Kryptonita (2011), de Leonardo Oyola, trabajan en la misma línea de descentralización.

Las doncellas, los débiles y los indefensos son el foco de protección y de justicia del paladín medieval. Los matices que la ficción neomedieval

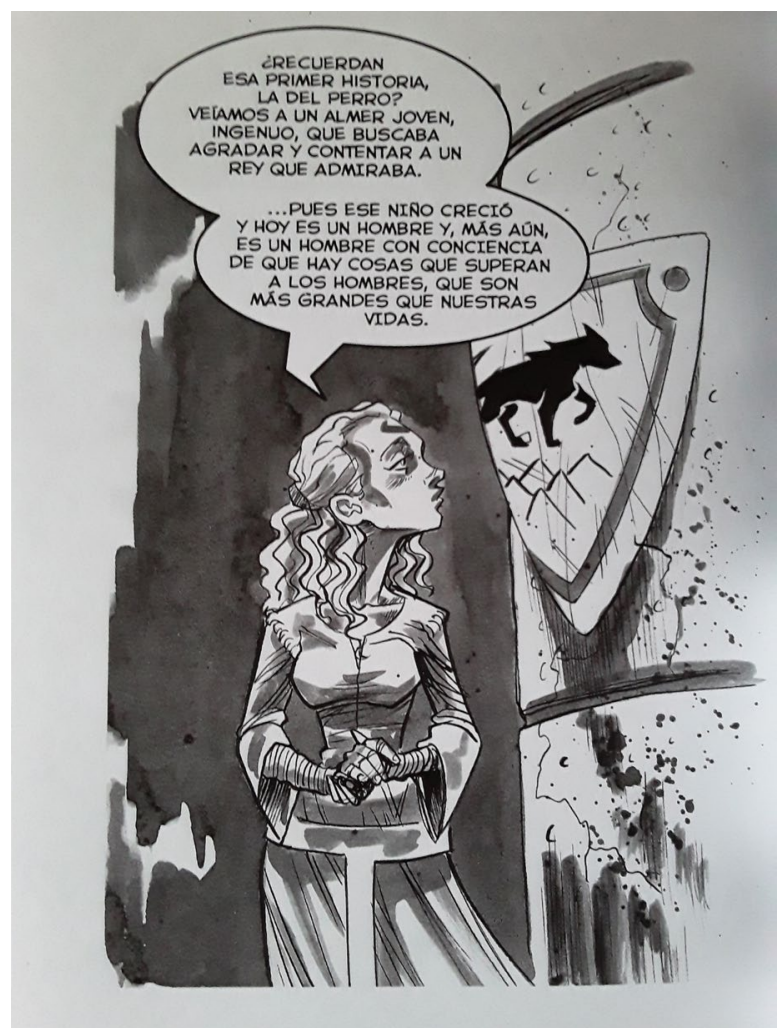

Almer integral, Manuel Loza 
toma en un territorio y en un tiempo otro hacen que el objeto de hazañas también varíe: el pueblo, los trabajadores y los oprimidos, es decir, los olvidados, son los que ampara Almer. Más significativo aún: son los que él elige proteger.

\section{Apéndice - Entrevista a Manuel Loza, 5 de octubre de 2021}

\section{¿Qué pensás que te influenció en Almer y qué creciste leyendo que esté relacionado?}

No sabría decir cuáles son mis influencias, generalmente me cuesta encontrarlas ahí, en mi trabajo. Puedo ver algo de dibujantes como Hugo Pratt, Jon Bogdanove o Frank Miller, lo demás me cuesta. Dentro de lo medieval fui un adolescente lector de El señor de los anillos, El Cantar de mio Cid y cuando era muy muy niño debo haber visto Excalibur de John Boorman como veinte veces.

Ya de adolescente mi abuelo me regaló Los hechos del rey Arturo y sus nobles caballeros, de John Steinbeck, y creo que lo leí dos veces de corrido; definitivamente Almer vive en ese Camelot.

Para cuando empecé la facu ya dedicaba cualquier sueldito que tuviera a comprarme cuanto libro de literatura medieval me encontrara; ahí fueron grandes hallazgos: los de la Biblioteca Medieval de editorial Alianza (de ahí sale el que todavía es mi favorito, que es La Vulgata) o, ya si quería hacer sacrificios fuertes, los de Sirvela editorial, que eran una maravilla (creo que Yvain o El Caballero del León, de Chrétien de Troyes, es mi favorito de esos).

\section{¿Conocés el Merlín de Wood y Alcatena?}

¡Sí! En los noventa me acuerdo que un amigo mío lo tenía en una edición de Columba con unas tapas horribles... ipero cómo se lo envidiaba! Tiempo después tuve revancha cuando la editorial Thalos lo publicó en un solo tomo y con una calidad preciosa. Lo compré y es lectura obligada cada vez que quiero volver a Almer.

\section{¿Cómo surgió la idea de Almer?}

Almer surge de una combinación de fascinaciones con Steinbeck, con la peli Excalibur, con la Vulgata y con haber jugado mucho rol cuando era más pibe. Creo que Almer termina siendo un ejercicio muy parecido al de El Príncipe Valiente de Harold Foster: las ganas de entrar en el universo del ciclo artúrico me hacen querer insertar en él a mi propio personaje, un joven caballero que va a vivir en ese mundo y participar como uno más de todas las vivencias de la Tabla Redonda. Es también una idea muy de juego de rol, el no interpretar a los personajes protagonistas de una historia sino insertar personajes nuevos que funcionen como testigos de esos eventos y mundos de aventuras.

En mi cabeza Almer vive entre escenas de la película Excalibur y la mayoría de los personajes clásicos del ciclo artúrico están a partir de la interpretación que les dio John Steinbeck. 
¿Cuánto de investigación sobre la materia artúrica hay en tu trabajo de composición?

No sé si decirle investigación porque en realidad es puro placer, soy muy fan de la literatura medieval, vivo comprándome libros y leyendo y releyendo. En ese sentido, hay muchísima investigación porque hay muchísima lectura previa, pero sin otra finalidad que la de divertirme.

Aparte de eso soy muy fan de los lores, de respetarlos y ver cómo puedo trabajar a Almer sin alterar los eventos que hacen al ciclo artúrico.

¿Por qué dentro de los personajes del universo artúrico les das más protagonismo a Nynyve y Gawain que a otros?

En el caso de Nyneve estoy totalmente enamorado de ella y de la construcción que hizo Steinbeck de la vida que tiene después de haber matado a Merlín. Me encanta y creo que Nyneve es un personaje espejo donde se ve reflejada la ideología del lector: hay quienes leen el ciclo artúrico y ven en Nyneve el arquetipo de la mujer seductora e histérica que manipuló a ese pobre viejito y hay quienes, como Steinbeck, ven en Nyneve a una piba que escapó como pudo del acoso de un tipo increíblemente poderoso y de la condena social (y mágica, claro) que ello le trajo. La Nyneve paria, mágica e inmortal que recorre un mundo que la rechaza me parece un personajazo, es todo tragedia.

Gawain, por otro lado, es el caballero engreído y canchero que mejor dinámica vincular puede tener con un pibe sensible y timidón como Almer. Son dos personajes que se quieren mucho pero que no podrían ser más distintos, y los diálogos resultantes están buenísimos para escribir.

Al momento de la creación de una historieta medieval desde nuestro contexto, ¿tuviste en cuenta algunas particularidades en la adaptación del imaginario de ese mundo? ¿ Creés que se vio permeado por algo local?

Yo creo que Almer es todo local. Ni bien salió hubo una nota en Página/12 que decía que Almer era un caballero medieval en la corte del rey Arturo pero que todo el tiempo se sentía como un pibe del conurbano [ver nota 22]. Eso fue lo más lindo que me dijeron en la vida porque habla del ejercicio de la apropiación, de tomar un elemento ajeno y hacerlo personal al mismo tiempo que siga siendo reconocible. Si eso me salió bien ya está, puedo dormir tranquilo.

A partir de la presentación biográfica en Almer definitivo (i. e. la aclaración de Indiana Jones y la aventura), ¿̇cómo es tu relación con la Facultad, con el ámbito académico y de la enseñanza?

Soy hijo de docentes y un eterno enamorado de la educación pública, es mi mayor fuente de ingresos $y$, sobre todo, mi hogar y trinchera.

La Facultad me parece un lugar superinteresante porque trabajo en materias de producción teórica e investigación en las que todos los procedimientos de la investigación conceptual están siendo constantemente analizados y eso me lleva a estar todo el tiempo pensando en las historietas que hago, cómo 
las hago y por qué las hago. Trabajar en un ámbito que te incentive tanto a la reflexión es un golazo.

¿Pensás volver a trabajar con estos personajes o con algún otro proyecto vinculado con lo medieval?

Sí, siempre quiero ir resolviendo compromisos y dedicarme de una buena vez a Almer de forma exclusiva, tengo muchísimas aventuras suyas para contar. 


\section{Bibliografía}

Alcatena, Enrique (2017), «Prólogo», en Almer definitivo, Buenos Aires, Big Sur Colectivo Editorial.

BLANC, William (2016), Le roi Arthur, un mythe contemporain, París, Libertalia.

Cipponerl, Gabriela y Kaila Yankelevich (2020), «Magia, religión y ciencia en disputa: el ocaso del reino artúrico en dos cómics»), Prácticas de oficio, 24, pp. 61-78.

EISNER, Will (1985), Comics and Sequential Art, Florida, Poorhouse Press.

Gallo León, José Pablo y María Victoria Játiva Miralles (2017), «Cómic y Edad Media: del escenario a la didáctica», en Antonio Huertas Morales (ed.), Edad Media contemporánea, Storyca, Monografías de Aula Medieval, 6, pp. 124-38.

Lacalle, Juan Manuel (2012), " "Or pourpensons un jeu": un recorrido musical a través del Jeu de Robin et Marion», en Ana Basarte y Santiago Barreiro, (eds.), Actas de las XI Jornadas Internacionales de Estudios Medievales y XXI Curso de Actualización en Historia Medieval, Buenos Aires, Sociedad Argentina de Estudios Medievales, pp. 121-7.

Llosa SANZ, Álvaro (2019), «Del Capitán Trueno a Robin de Luxley: magia, hechicería e Inquisición en el cómic contemporáneo español de tema medieval», Magia, brujería, Inquisición, Storyca, Monografías de Aula Medieval, 10, pp. 117-42.

Loza, Manuel (2017), Almer definitivo, Buenos Aires, Big Sur Colectivo Editorial. LozA, Manuel (2016), Almer integral, Lanús, Atmósfera.

MCCLOUd, Scott (1994), Understanding Comics. The Invisible Art, Nueva York, Harper Collins.

Pastoureau, Michel (2011), Bestiaires du Moyen Âge, París, Sevil.

Pastoureau, Michel (2013/2004), Una historia simbólica de la Edad Media occidental, trad. de Julia Bucci, Buenos Aires, Katz.

SteinBECK, John (1977/1976), Los hechos del rey Arturo y sus nobles caballeros, Buenos Aires: Sudamericana.

TOLKIEN, J. R. R. (2001/1954]), The Lord of the Rings, Londres, Harper Collins.

Torregrossa, Michael (2004), «Once and Future Kings: The Return of King Arthur in the Comicsy, en Barbara Tepa Lupack (ed.), Adapting the Arthurian Legends for Children, Nueva York, Palgrave Macmillan, pp. 243-62. Zumthor, Paul (2016/1978), "Génesis y evolución del género», en Lidia Amor y Ana Basarte (comps.), El Roman Medieval, Buenos Aires, Oficina de Publicaciones de la Facultad de Filosofía y Letras. 
Cipponerl, Gabriela; Juan Manuel Lacalle y Kaila YanKeleVICH, «El caballero del pueblo, los trabajadores y los oprimidos: una lectura de Almer, cómic neomedieval argentinon, Storyca 3 (2021), pp. 13-37.

https://doi.org/10.51863/Storyca.2021.CipponeriLacalleyYankelevich

\section{Resumen}

La historieta contemporánea latinoamericana que toma el imaginario medieval como base de su construcción ficcional no ha sido suficientemente estudiada por la crítica. En este artículo nos proponemos llevar a cabo un análisis de la serie Almer, del argentino Manuel Loza, publicada durante la segunda década del siglo XXI. Nos centramos, por un lado, en las continuidades que esta ficción presenta con la materia medievaly, por otro lado, en las particularidades que adquieren los personajes y las aventuras acaecidas en un contexto diverso. Entre estos aspectos se destaca la reelaboración de un elemento particular del mito artúrico, la igualdad entre pares, para la creación de un caballero novedoso cuya tarea es, fundamentalmente, la de proteger a los trabajadores y los oprimidos de la sociedad. Al final se incluye como apéndice una entrevista realizada al autor en 2021 con motivo del presente número de Storyca.

\section{Abstract}

Contemporary Latin-American comics that adopt the medieval world as the basis of their fictional creation have not been sufficiently studied by scholars. In this article we propose to carry out an analysis of the series Almer, by the Argentinian author Manuel Loza, published during the second decade of the $21^{\text {st }}$ century. We focus, on the one hand, on the extensions of the medieval matter found in this fiction and, on the other hand, on the peculiarities that the characters have and the adventures that take place in a diverse context. Among these aspects we highlight the redefinition of one of the elements of the Arthurian myth, that of equality among peers, in order to create a novel

\section{Palabras clave}

Historieta

Neomedievalismo Materia artúrica Argentina Caballería

\section{KeyWords}

Comic Neomedievalism Arthurian legend Argentina Knighthood 
knight whose task is, above all, to protect laborers and the oppressed in society. At the end we include, as an appendix, an interview conducted to the author in 2021 on the occasion of the current volume of Storyca. 